\title{
Effect of abomasal glucose infusion on splanchnic and whole-body glucose metabolism in periparturient dairy cows
}

\author{
M. Larsen and N. B. Kristensen ${ }^{1}$ \\ Department of Animal Health, Welfare and Nutrition, Faculty of Agricultural Sciences, Aarhus University, DK-8830 Tjele, Denmark
}

\begin{abstract}
Six periparturient Holstein cows fitted with ruminal cannulas and permanent indwelling catheters in the hepatic portal vein, hepatic vein, mesenteric vein, and an artery were used to study the effects of abomasal glucose infusion on splanchnic and whole-body glucose metabolism. The experimental design was a split plot, with cow as the whole plot, treatment as the whole-plot factor, and days in milk (DIM) as the subplot factor. Cows were assigned to 1 of 2 treatments: the control (no infusion) or infusion $(1,500 \mathrm{~g} / \mathrm{d}$ of glucose infused into the abomasum from the day of calving). Cows were sampled at $12 \mathrm{~d}$ prepartum and at 4, 15, and 29 DIM. To study portal-drained visceral uptake of arterial glucose, $\left[\mathrm{U}-^{13} \mathrm{C}\right]$ glucose was continuously infused into the jugular vein on sampling days. Postpartum, voluntary dry matter intake and milk yield increased at a lower rate with the infusion compared with the control. The net portal flux of glucose increased with the infusion compared with the control, and $67 \pm 5 \%$ of the infused glucose was recovered as increased portal flux of glucose. The net hepatic flux of glucose was lower with the infusion compared with the control; however, the net hepatic flux of glucose per kilogram of dry matter intake was not affected by treatment. The arterial concentrations of glucose and insulin decreased and concentrations of nonesterified fatty acids increased from prepartum to 4 DIM with the control, but these effects were not observed with the infusion. The arterial concentration of $\beta$-hydroxybutyrate decreased more from prepartum to 4 DIM with the infusion, compared with the control. Uptake of arterial $\left[\mathrm{U}_{-}{ }^{13} \mathrm{C}\right]$ glucose in the portal-drained viscera was affected neither by the infusion nor by the DIM and averaged $2.5 \pm 0.2 \%$. The whole-body glucose supply changed to be less dependent on the recycling of lactate (Cori cycle) with the infusion. It was concluded that small intestinal glucose absorption is an efficient source of glucose to the peripheral tissues of dairy cows in very early lactation. At least $67 \%$ of the available
\end{abstract}

Received June 13, 2008.

Accepted October 8, 2008.

${ }^{1}$ Corresponding author: nbk@agrsci.dk glucose was recovered in the portal vein without affecting hepatic gluconeogenesis. Infused cows produced less milk and had a lower feed intake, indicating that an improved glucogenic status in very early lactation impaired metabolic adaptations to lactation.

Key words: dairy cow, glucose, metabolism, transition

\section{INTRODUCTION}

Within a few days after calving, the nutrient demand for milk synthesis in the mammary gland is several fold that of the pregnant uterus, but the corresponding increase in feed intake is not sufficient to meet the increased demand (Bell, 1995; Drackley, 1999). This leads to nutritional imbalances for the first weeks after calving and potentially has great implications for the health, production, and overall well-being of the cows (Grummer, 1995). To alleviate the deficient supply of nutrients, a range of metabolic processes are adapted in the cow; for example, liver gluconeogenesis and the mobilization of body reserves are upregulated (Bell, 1995; Drackley et al., 2001). Even though hepatic gluconeogenesis is increased, periparturient cows often suffer from hypoglycemia and, in combination with hyperlipidemia, the risk for accumulation of ketone bodies is great.

Grummer (1995) emphasized the potential benefits of preventing hepatic lipid accumulation and glycogen depletion by decreasing fat mobilization from adipose tissues by manipulating the endocrine status. Increasing the glucogenic status of the periparturient cow could be a way to obtain the desired change in endocrine status; thus, feeding diets that increase small intestinal glucose absorption could be a safe and attractive strategy to obtain both an increased direct exogenous glucose supply and decreased fat mobilization. However, the efficacy of increasing the peripheral tissue supply of glucose via small intestinal glucose absorption depends on the capacity for starch hydrolysis, the absorption capacity, and the metabolic response of splanchnic tissues (Harmon et al., 2004). Our hypothesis was that increased absorption of glucose from the small intestine would increase portal-drained visceral (PDV) uptake 
of arterial glucose, decrease hepatic glucose output, and increase milk yield because of an overall increase in glucose availability to peripheral tissues. The objectives of the present study were to measure the effects of abomasal glucose infusion in periparturient dairy cows on splanchnic and whole-body glucose metabolism by using the multicatheterization technique in combination with infusion of $\left[\mathrm{U}_{-}{ }^{13} \mathrm{C}\right]$ glucose.

\section{MATERIALS AND METHODS}

The present experiment complied with Danish Ministry of Justice Law No. 382 (June 10, 1987), Act No. 726 (September 9, 1993) concerning experiments with animals and care of experimental animals.

\section{Animals and Experimental Design}

Six Danish Holstein cows entering their second lactation were used in a split-plot design, with cow as the whole plot, treatment as the whole-plot factor, and DIM as the subplot factor. Cows were randomly assigned to 1 of 2 treatments: no infusion (control, C) or a continuous abomasal infusion of $1,500 \mathrm{~g} / \mathrm{d}$ of glucose initiated on the day of calving (infusion, I). The glucose infusion was stepped up by $500 \mathrm{~g} / \mathrm{d}$ over $3 \mathrm{~d}$. Cows were sampled prepartum $(12 \pm 6 \mathrm{~d})$ to assess the effects of treatment on metabolic changes during transition. Postpartum, cows were sampled at 4, 15, and 29 DIM. Ruminal cannulas and permanent indwelling catheters in the mesenteric vein, mesenteric artery $(\mathrm{n}=$ $3)$, intercostal artery $(\mathrm{n}=3)$, hepatic portal vein, and hepatic vein $(\mathrm{n}=5$; one cow in the $\mathrm{C}$ treatment did not have a functional hepatic vein catheter) were implanted during the dry period at least 6 wk before expected calving. Surgery was done according to Kristensen et al. (2007), except that intercostal catheterization was performed under infiltration analgesia. The artery was exposed in the last intercostal space and a Tygon catheter $(1.02 \mathrm{~mm}$ i.d. $\times 1.78 \mathrm{~mm}$ o.d.; S-54-HL, Buch \& Holm A/S, Herlev, Denmark) was inserted $35 \mathrm{~cm}$ into the artery, placing the tip of the catheter in the aorta. Cows were housed in tie stalls with rubber mats and straw bedding.

All cows were offered the same nonlactation ration prepartum and the same lactation ration postpartum (Table 1), composed to fulfill the Danish recommendations for nutrient allowances. The cows had access to salt mineral blocks (KNZ Tradition, KNZ Salt Licks, Hengelo, the Netherlands). The feed intake in the last 3 wk prepartum was restricted to $10 \mathrm{~kg}$ of DM/d. Postpartum, cows were fed ad libitum ( $10 \%$ orts) a ration optimized to an average feed intake of $20.3 \mathrm{~kg}$ of DM/d. Rations were offered as TMR and fed in equally sized
Table 1. Composition of nonlactation and lactation $\mathrm{TMR}^{1}(\mathrm{~g} / \mathrm{kg}$ of $\mathrm{DM})$

\begin{tabular}{lcc}
\hline Item & Nonlactation & Lactation \\
\hline Ingredient & & \\
Corn silage & 495 & 410 \\
Clover grass silage & 225 & 200 \\
Barley, rolled & 150 & 150 \\
Rapeseed cake & 42.5 & 95.0 \\
Molasses, sugar beet & & 70.0 \\
Sugar beet pulp, dried & 25.0 & 25.0 \\
Soybean meal, $49 \%$ CP & 7.5 & 17.5 \\
Vegetable fat ${ }^{2}$ & 15.0 & 7.5 \\
NaCl & 7.5 & \\
NaHCO ${ }_{3}$ & & 7.5 \\
Mineral and vitamin premix & $12.5^{3}$ & $7.5^{4}$ \\
Biotin premix & & \\
Nutrient & 20.0 & 10.0 \\
DM & $393 \pm 2$ & $422 \pm 3$ \\
Ash & 80 & 75 \\
CP & 133 & 156 \\
Crude fat & 39 & 35 \\
NDF & 353 & 314 \\
Starch & 182 & 178 \\
Digestible energy, ${ }^{6}$ MJ/kg of DM & 13.4 & 13.8 \\
\hline
\end{tabular}

${ }^{1}$ Rations were composed to fulfill the Danish recommendations for nutrient allowances.

${ }^{2}$ Vegetable fat (Leci-E, Evilec, Kolding, Denmark) with 50\% rapeseed and soybean lecithin and natural $\alpha$-tocopherol containing (per $\mathrm{kg}$ of $\mathrm{DM}$ ): $950 \mathrm{~g}$ of crude fat, $836 \mathrm{~g}$ of fatty acids, and 2,000 $\mathrm{mg}$ of $R R R$ $\alpha$-tocopherol.

${ }^{3}$ Premix dry (Mikro G, DLG, Copenhagen, Denmark) containing (per $\mathrm{kg}$ ): $20 \mathrm{~g}$ of $\mathrm{Ca}, 50 \mathrm{~g}$ of P, $140 \mathrm{~g}$ of $\mathrm{Mg}, 9 \mathrm{~g}$ of Na, $6 \mathrm{~g}$ of S, $600 \mathrm{kIU}$ of vitamin A, $190 \mathrm{kIU}$ of vitamin D, 8,000 $\mathrm{mg}$ of $\alpha$-tocopherol, 4,000 $\mathrm{mg}$ of $\mathrm{Mn}, 900 \mathrm{mg}$ of $\mathrm{Cu}, 25 \mathrm{mg}$ of $\mathrm{Co}, 4,500 \mathrm{mg}$ of $\mathrm{Zn}, 225 \mathrm{mg}$ of I, and $50 \mathrm{mg}$ of Se.

${ }^{4}$ Premix lactation (Mikro 1, DLG, Copenhagen, Denmark) containing (per $\mathrm{kg}$ ): $180 \mathrm{~g}$ of $\mathrm{Ca}, 4 \mathrm{~g}$ of $\mathrm{P}, 65 \mathrm{~g}$ of $\mathrm{Mg}, 80 \mathrm{~g}$ of $\mathrm{Na}, 30 \mathrm{~g}$ of S, 693 kIU of vitamin A, $146 \mathrm{kIU}$ of vitamin D, 4,620 $\mathrm{mg}$ of $\alpha$-tocopherol, $3,080 \mathrm{mg}$ of $\mathrm{Mn}, 693 \mathrm{mg}$ of $\mathrm{Cu}, 19 \mathrm{mg}$ of Co, 3,460 mg of Zn, $173 \mathrm{mg}$ of I, and $38.5 \mathrm{mg}$ of Se.

${ }^{5}$ Biotin premix (Suplex Biotin, Vitfoss, Gråsten, Denmark) containing (per $\mathrm{kg}$ ): $171.5 \mathrm{~g}$ of $\mathrm{Ca}, 3.5 \mathrm{~g}$ of $\mathrm{P}, 0.1 \mathrm{~g}$ of $\mathrm{Na}$, and $100 \mathrm{mg}$ of biotin. ${ }^{6}$ Calculated from ingredients according to the Danish feed evaluation system.

meals at 0800,1600 , and $2400 \mathrm{~h}$. Orts were removed at $0730 \mathrm{~h}$ and cows were milked at 0530 and $1530 \mathrm{~h}$. Ration compositions were adjusted weekly for the average DM content of ingredients during the preceding week. At the day of calving, all cows received $700 \mathrm{~g}$ of an electrolyte mixture containing $71 \%$ calcium propionate and $21 \%$ magnesium sulfate (Selekt Nykælver, Pharmalett A/S, Kolding, Denmark) dissolved in $20 \mathrm{~L}$ of warm tap water and administered manually via the ruminal cannula.

\section{Abomasal Infusion}

With the I treatment, an infusion device was placed in the abomasum via the ruminal cannula on the day of calving. The infusion device was constructed from 180 


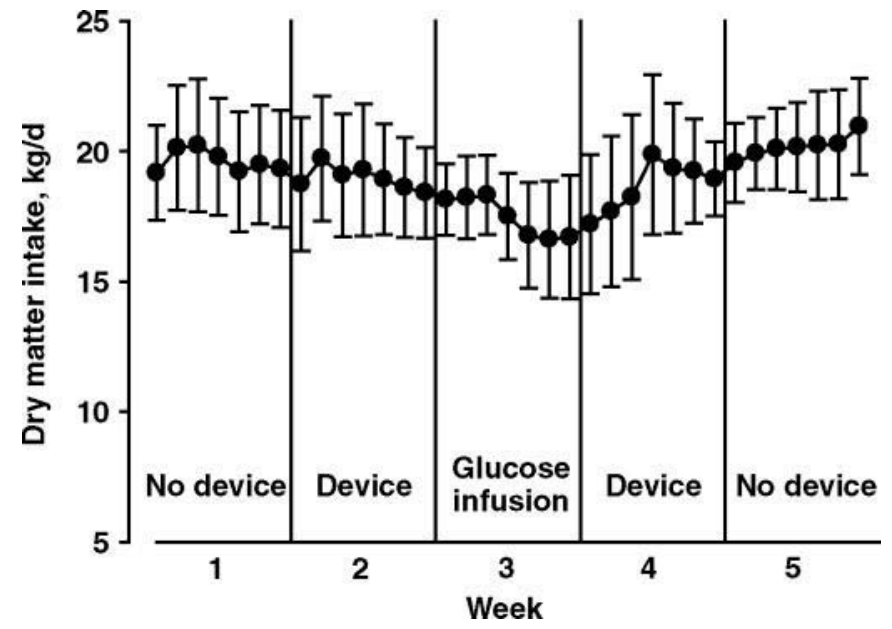

Figure 1. Test experiment with 3 ad libitum-fed lactating dairy cows in a cross-back design with 5 periods of 1 wk to check the durability and risk of imposing secondary effects on the cows using the abomasal infusion device. Periods were as follows: No device, Device, Glucose infusion, Device, and No device. Infusion was $1,500 \mathrm{~g} / \mathrm{d}$ of glucose into the abomasum. Each data point is the least squares mean of 3 observations $\pm \mathrm{SE}$.

$\mathrm{cm}$ of reinforced rubber hose $(1 / 2$ in.) attached to a ruminal cannula plug in the proximal end and a flexible rubber disc at the distal end to secure the placement in the abomasum. The flexible rubber disc was made from a 10-cm ruminal cannula plug (no. 1S, Bar Diamond Inc., Parma, ID), by cutting the hard inner flange, leaving a soft and flexible concave rubber disc of $14 \mathrm{~cm}$ in diameter. An unbroken infusion line (silicone tube: $3 \mathrm{~mm}$ i.d., $6 \mathrm{~mm}$ o.d.; Ole Dich Instrumentmakers, Hvidovre, Denmark) was inserted through the rubber hose and fixed at both ends with silicone glue. The infusate was prepared daily by dissolving 1,648 $\mathrm{g}$ of dextrose (C*dex 02001, Cargill Nordic, Charlottenlund, Denmark) in $7,952 \mathrm{~g}$ of tap water and was infused by a peristaltic pump (Type 115/G42 with L-channels, Ole Dich Instrumentmakers) at a rate of $398 \pm 2 \mathrm{~g} / \mathrm{h}$.

The infusion device was tested by using 3 ad libitumfed ruminally cannulated dairy cows in mid- and late lactation to check the durability and risk of imposing secondary effects on the cows with the device. The test was designed as a cross-back design with 5 periods: no device, device with no infusion, device with glucose infusion $(1,500 \mathrm{~g} / \mathrm{d})$, device with no infusion, and no device. Figure 1 shows the voluntary daily DMI of the 3 cows during the test. No abrupt changes in feed intake or general appearance of the cows by introducing the device were observed, whereas initiation of glucose infusion decreased DMI. From the test experiment, it was concluded that the infusion device, as constructed and used in the present experiment, was without a major negative impact on the cows and was probably even less stressing for cows in the present study than for cows in the test experiment because the reticuloomasal orifice felt relaxed on the day of calving.

\section{Experimental Sampling and Data Collection}

Eight hourly sample sets of ruminal fluid and arterial, portal vein, and hepatic vein blood were obtained, beginning $30 \mathrm{~min}$ before feeding at $0800 \mathrm{~h}$. A total of 30 $\mathrm{mL}$ of blood was collected from each catheter at each sampling time, and blood was immediately stabilized in either heparin vacuettes (no. 455051, Greiner BioOne $\mathrm{GmbH}$, Frickenhausen, Austria) or $\mathrm{K}_{3}$ EDTA vacuettes (no. 455036, Greiner BioOne GmbH). Blood samples were placed on crushed ice, and plasma was harvested by centrifugation at $3,000 \times g$ for $20 \mathrm{~min}$ at $4^{\circ} \mathrm{C}$. Plasma was stored at $-20^{\circ} \mathrm{C}$ until analysis. Separate sets of blood samples were collected into heparinized 1-mL syringes before collecting the main samples for immediate determination of oximetry variables and $\mathrm{pH}(\mathrm{ABL}$ 520, Radiometer A/S, Copenhagen, Denmark). Ruminal fluid was sampled from the ventral ruminal sac by a 50-mL syringe and a suction strainer (RT extended model, Bar Diamond Inc.). Ruminal fluid $\mathrm{pH}$ was measured immediately (IQ 150 pH meter, IQ Scientific Inc., Carlsbad, CA). An 8-mL subsample of ruminal fluid was stabilized by adding $2 \mathrm{~mL}$ of $25 \%$ metaphosphoric acid and stored at $-20^{\circ} \mathrm{C}$ until analysis.

Blood plasma flow was determined by measuring downstream dilution of $p$-aminohippuric acid (175 $\mathrm{mmol} / \mathrm{L}$ ) infused continuously into a mesenteric vein at $36.4 \pm 1.3 \mathrm{mmol} / \mathrm{h}$, initiated $1 \mathrm{~h}$ before the first sampling time. Primed (60 $\mathrm{mL}$ of infusate) continuous infusion $(7.58 \mathrm{mmol} / \mathrm{L}, 0.75 \pm 0.06 \mathrm{mmol} / \mathrm{h}$ prepartum; and $22.73 \mathrm{mmol} / \mathrm{L}, 1.97 \pm 0.07 \mathrm{mmol} / \mathrm{h}$ postpartum) of $\left[\mathrm{U}_{-}{ }^{13} \mathrm{C}\right]$ glucose $\left(\mathrm{U}_{-}{ }^{13} \mathrm{C}_{6}, 99 \%\right.$, tested for sterility and pyrogenicity; Cambridge Isotope Lab. Inc., Andover, MA) into the jugular vein was initiated $1 \mathrm{~h}$ before the first sampling time.

Milk yield and feed intake were recorded daily. Samples for the measurement of milk constituents were collected on sampling days. Rations were sampled weekly for DM determination, and the dried samples were pooled within ration for chemical analysis. Feces were sampled in the morning and afternoon of the sampling days. Feces samples were pooled within cow and sampling day and were stored at $-20^{\circ} \mathrm{C}$ until analysis. Cows were weighed before the afternoon milking of each sampling day.

\section{Analytical Procedures}

Plasma samples were analyzed for glucose and lactate by using D-glucose oxidase and L-lactate oxidase, 
respectively (YSI 7100, YSI Inc., Yellow Springs, OH). Plasma concentrations of $p$-aminohippuric acid were determined by using the method described by Harvey and Brothers (1962), modified to run on a Cobas Mira autoanalyzer (Triolab A/S, Brøndby, Denmark). Plasma concentrations of BHBA and NEFA (EDTA plasma) were determined by using enzymatic assays (RB 1008 and FA 115, respectively; Randox Laboratories Ltd., Crumlin, UK) adapted for use on a Cobas Mira autoanalyzer. Plasma abundance of $\left[\mathrm{U}_{-}^{13} \mathrm{C}\right]$ glucose carbon was determined by GC-isotope ratio MS according to Kristensen et al. (2002). Plasma insulin and IGF-I were determined by time-resolved fluoroimmunometric assays according to Løvendahl and Purup (2002) and Frystyk et al. (1995), respectively. Hematocrit was determined immediately on heparin-stabilized arterial samples by centrifugation in capillary tubes at 13,000 $\times g$ and $20^{\circ} \mathrm{C}$ for $6 \mathrm{~min}$.

Ruminal samples were analyzed for VFA by GC as described by Kristensen et al. (1996). Glucose and lactate in ruminal fluid were determined by using the YSI analyzer (YSI Inc.) as described for plasma samples. Ammonia in ruminal samples were determined after 1:20 dilution with $100 \mathrm{~m} M$ phosphate buffer by using an enzymatic assay (AM 1015, Randox Laboratories Ltd.) adapted for use on a Cobas Mira autoanalyzer. Feed samples were analyzed for DM, ash, CP, crude fat, NDF, and starch as described by Kristensen et al. (2007). Dry matter and starch concentrations in feces were determined as described for feed samples. The VFA, glucose, and lactate concentrations in fecal liquid were determined as described for ruminal fluid. The fecal liquid was extracted from $10 \mathrm{~g}$ of thawed feces combined with $10 \mathrm{~mL}$ of $10 \%$ metaphosphoric acid and stored at $-20^{\circ} \mathrm{C}$ until analysis. Milk samples were analyzed for fat, protein, lactose, and urea by infrared spectroscopy with a MilkoScan 4000 (Foss Electric, Hillerød, Denmark).

\section{Calculations and Statistical Procedures}

Calculations of net portal, net hepatic, and net splanchnic metabolite fluxes were performed as described by Kristensen et al. (2007). The PDV uptake of arterial glucose was calculated as described for acetate by Kristensen et al. (1996). Data were subjected to ANOVA according to a split-plot design, where the whole plot (cow) was considered as a random factor. Data on ruminal and arterial variables, blood plasma flows, and metabolite fluxes were analyzed by using a model including the fixed effects of treatment, DIM, and sampling time (Time), and the possible interactions. Time within cow by DIM were considered as repeated measures by using an autoregressive order 1 covariance structure, because this covariance structure was generally found to fit well to the present type of time series. Variables with only one observation within cow and sampling day were analyzed by using a reduced model, not including the effect of Time. Least squares means \pm standard errors of the means are presented because there were missing observations for the hepatic variables: one observation was missing with the prepartum $\mathrm{C}$ treatment, the 4 DIM C treatment, the 29 DIM C treatment, and the 29 DIM I treatment; 2 observations were missing with the 15 DIM C treatment. A paired Student's $t$-test was used to separate treatment means within DIM protected by the overall $F$-test. A paired Student's $t$-test was used to test whether the prepartum $\mathrm{C}$ to the 4 DIM C treatment differed from the prepartum I to the 4 DIM I treatment (named $P_{\text {trans } \times \text { trt }}$ in tables). Significance was declared at $P \leq 0.05$, and tendencies were considered at $0.05<P \leq 0.10$.

\section{RESULTS}

No calving problems were observed. Except for some unproblematic incidences of mastitis and a single incidence of retained placenta, no illnesses were observed (Table 2).

\section{Feed Intake, Milk Yield, and BW}

Voluntary DMI increased at a decreased rate $(P=$ 0.05; Figure 2a and Table 3) and the overall treatment mean was $6.2 \mathrm{~kg} / \mathrm{d}$ lower with the I than the C treatment. The infusion rate of glucose into the abomasum obtained at sampling days was $349 \pm 6 \mathrm{mmol} / \mathrm{h}$, equivalent to $1,501 \pm 25 \mathrm{~g} / \mathrm{d}$.

There was an interaction $(P=0.04$; Figure $2 \mathrm{~b}$ and Table 3) between treatment and DIM for milk yield, reflecting a markedly reduced rate of increase for milk

Table 2. Mean BCS of cows at drying off, mean calf birth weights, and treated illnesses

\begin{tabular}{lcc}
\hline & \multicolumn{2}{c}{ Treatment group $^{1}$} \\
\cline { 2 - 3 } Item & Control & Infusion \\
\hline BCS at dry off & $2.5 \pm 0.0$ & $2.7 \pm 0.4$ \\
Calf birth weight, kg & $36 \pm 2$ & $40 \pm 3$ \\
Treated illnesses, $\mathrm{n}$ & 0 & 0 \\
Calving problems & 2 & 3 \\
Mastitis & 1 & 0 \\
Metritis & 0 & 0 \\
Milk fever & 0 & 0 \\
Displaced abomasum & 0 & 0 \\
Digestion disorders & 0 & 0 \\
Other & 0 & \\
\hline
\end{tabular}

${ }^{1}$ Treatments were the control or a continuous infusion of $349 \pm 6 \mathrm{mmol}$ of glucose/h into the abomasum from 1 to 29 DIM. 

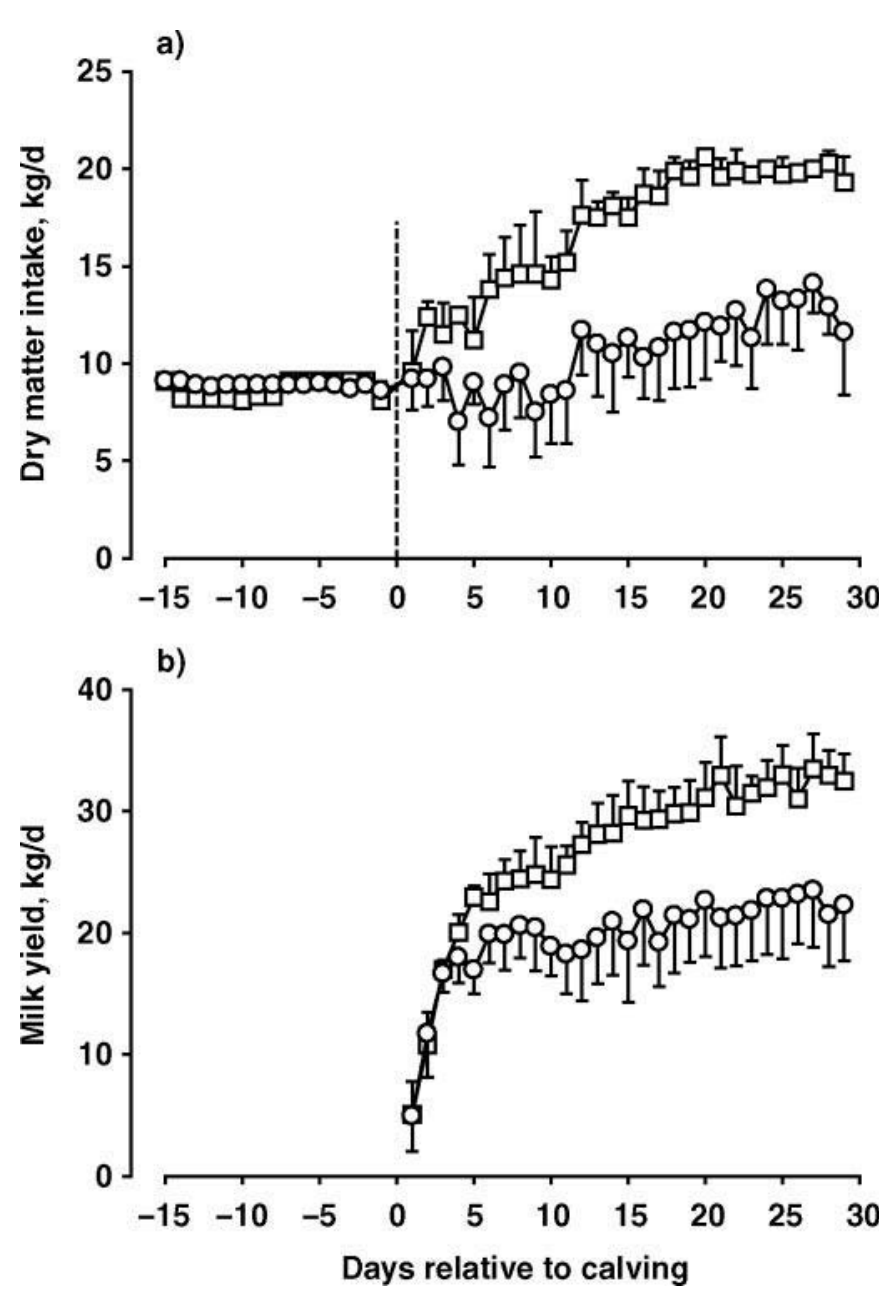

Figure 2. Voluntary DMI (a) and milk yield (b) in dairy cows with either no infusion $[\square$, control $(\mathrm{C})]$ or continuous abomasal infusion of $349 \pm 6 \mathrm{mmol}$ of glucose/h [O, infusion (I)] from the day of calving. Each data point is the least squares mean of 3 observations \pm SE. Postpartum, DMI increased at a lower rate $(P=0.05)$ with the I treatment compared with the $\mathrm{C}$ treatment. An interaction $(P=0.04)$ between treatment and DIM was observed for milk yield.

yield from approximately 4 DIM with the I treatment compared with the $\mathrm{C}$ treatment. Correspondingly, there was an interaction $(P=0.02$ to $P=0.09)$ between treatment and DIM for yield of milk constituents. Milk composition was not affected $(P=0.12$ to $P=0.51)$ by treatment (Table 3), but from 4 to 15 DIM, the overall concentrations of fat, protein, and urea decreased $(P$ $<0.01$ to $P=0.04)$ and the lactose concentration increased $(P<0.01)$.

Animal BW decreased similarly $(P=0.90)$ from prepartum to 4 DIM with both treatments. Postpartum, there was an interaction $(P=0.03)$ between treatment and DIM, because the weight decreased further from 4 to 15 DIM with the I treatment, whereas the weight was unchanged from 4 to 29 DIM with the $\mathrm{C}$ treatment.

\section{Fecal Variables}

Fecal DM tended to be lower $(P=0.08)$ with the I treatment, and decreased $(P<0.01)$ with increasing DIM with both treatments (Table 4$)$. The starch concentration in feces did not differ $(P=0.77)$ between treatments but increased $(P=0.05)$ with increasing DIM, showing a peak at 15 DIM.

The glucose concentration and the molar proportion of butyrate in fecal liquid tended to increase more $(P$ $<0.10)$ from prepartum to 4 DIM with the I than the C treatment. A tendency for an interaction $(P=0.10)$ between treatment and DIM was observed for the fecal glucose concentration postpartum and reflected the increase at 4 DIM with the I treatment. The molar proportion of butyrate was increased $(P=0.05)$ at 4 DIM with the I treatment compared with all other treatment $\times$ DIM combinations. The concentration of total VFA in fecal liquid was lower $(P=0.01)$ at 15 and 29 DIM with the I than the $\mathrm{C}$ treatment. The proportion of valerate was lower $(P=0.01)$ with the $\mathrm{I}$ than the $\mathrm{C}$ treatment.

\section{Ruminal Variables}

The ruminal variables were generally not affected by treatment $(P=0.14$ to $P=0.83$; Table 5$)$; however, an interaction $(P=0.01)$ was observed between treatment and DIM for the ruminal glucose concentration, indicating that the concentration increased with increasing DIM for the $\mathrm{C}$ treatment but decreased with the I treatment. Effects of Time $(P=0.09$ to $P<0.01)$ were observed for all measured ruminal variables except for $\mathrm{pH}$, total VFA, and the molar proportion of butyrate.

\section{Arterial Variables}

The arterial concentrations of glucose and insulin decreased ( $P=0.05$ and $P=0.03$, respectively) from prepartum to 4 DIM with the $\mathrm{C}$ treatment, but no changes in glucose and insulin during transition were observed with the I treatment (Table 6). Correspondingly, the arterial concentration of BHBA decreased more $(P<$ $0.01)$ and the concentration of NEFA tended to increase less $(P=0.06)$ from prepartum to 4 DIM with the I than the $\mathrm{C}$ treatment. As lactation progressed beyond 4 DIM, the arterial NEFA concentration decreased $(P$ $<0.01)$ for both treatments. Postpartum, there was an interaction $(P<0.01)$ between treatment and DIM for the arterial concentration of BHBA, reflecting an increasing concentration with increasing DIM with the C treatment, compared with a consistently low concentration with the I treatment. The arterial concentration of insulin tended to be greater $(P=0.07)$ with the I 
Table 3. Dry matter intake, milk yield, milk composition, and $\mathrm{BW}^{1}$

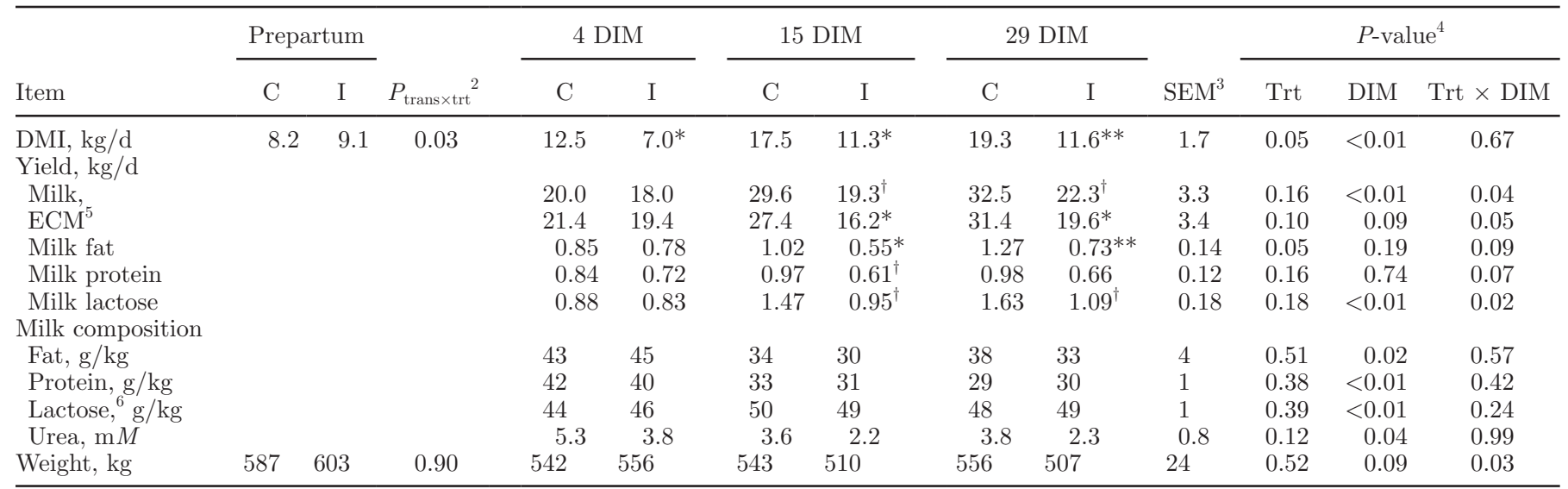

${ }^{1}$ Treatments were the control (C) or a continuous infusion (I) of $349 \pm 6 \mathrm{mmol}$ of glucose/h into the abomasum from 1 to 29 DIM.

${ }^{2}$ Student's $t$-test for prepartum C to 4 DIM C to differ from prepartum I to 4 DIM I.

${ }^{3} \mathrm{n}=3$, except for ECM and milk components for $\mathrm{C}$ at 29 DIM, where $\mathrm{n}=2$.

${ }^{4}$ Fixed effects when prepartum observations are excluded from the data set. Trt $=$ treatment.

${ }^{5}$ Calculated according to Sjaunja et al. (1991).

${ }^{6}$ Lactose monohydrate.

${ }^{* *} P \leq 0.01,{ }^{*} P \leq 0.05, \dagger P \leq 0.10$ : symbols signify a difference between LSM within DIM and rows.

than the $\mathrm{C}$ treatment, but the insulin concentration with the $\mathrm{C}$ treatment was gradually increased toward the concentration with the I treatment as lactation progressed. The arterial concentration of lactate decreased $(P=0.04)$ in parallel with both treatments as lactation progressed. Arterial IGF-I was decreased by $67 \%$ from prepartum to 4 DIM with both treatments and then increased $(P<0.01)$ in parallel with increasing DIM.
Arterial blood $\mathrm{pH}$, hematocrit, oxygen, and carbon dioxide concentrations were not affected $(P=0.35$ to $P$ $=0.75)$ by treatment. Arterial hematocrit and oxygen concentrations increased by $10 \%$ from prepartum to 4 DIM with both treatments and then decreased $(P<$ 0.01) in parallel with increasing DIM. Arterial blood $\mathrm{pH}$ decreased $(P<0.01)$ gradually from prepartum to 15 DIM.

Table 4. Fecal variables ${ }^{1}$

\begin{tabular}{|c|c|c|c|c|c|c|c|c|c|c|c|c|c|}
\hline Item & \multicolumn{2}{|c|}{ Prepartum } & $P_{\text {trans } \times \text { trt }}^{2}$ & \multicolumn{2}{|c|}{$4 \mathrm{DIM}$} & \multicolumn{2}{|c|}{15 DIM } & \multicolumn{2}{|c|}{29 DIM } & $\mathrm{SEM}^{3}$ & \multicolumn{3}{|c|}{$P$-value ${ }^{4}$} \\
\hline \multicolumn{14}{|l|}{ Whole feces } \\
\hline DM, \% & 13.8 & 12.6 & 0.93 & 14.9 & 13.5 & 13.1 & $10.4^{*}$ & 13.4 & 12.8 & 0.8 & 0.08 & $<0.01$ & 0.17 \\
\hline Starch, \% of DM & 0.57 & 0.40 & 0.43 & 0.45 & 0.51 & 0.91 & 0.84 & 0.49 & 0.61 & 0.15 & 0.77 & 0.05 & 0.80 \\
\hline \multicolumn{14}{|l|}{ Fecal liquid } \\
\hline Glucose, $\mathrm{m} M$ & 0.58 & 0.79 & 0.06 & 0.88 & $1.87^{*}$ & 0.97 & 0.88 & 1.27 & 1.41 & 0.23 & 0.23 & 0.15 & 0.10 \\
\hline Acetate, mol/100 mol & 77.9 & 76.2 & 0.37 & 75.0 & 69.7 & 77.2 & 76.2 & 76.5 & 78.3 & 1.9 & 0.42 & 0.08 & 0.31 \\
\hline Propionate, mol/100 mol & 14.8 & 15.5 & 0.66 & 16.4 & 18.8 & 15.4 & 14.8 & 15.9 & 13.3 & 2.0 & 0.88 & 0.39 & 0.54 \\
\hline Isobutyrate, $\mathrm{mol} / 100 \mathrm{~mol}$ & 1.3 & 1.7 & 0.03 & 1.1 & 0.7 & 1.1 & 1.4 & 1.2 & 1.0 & 0.2 & 0.60 & 0.11 & 0.18 \\
\hline Butyrate, mol/100 mol & 4.1 & 3.9 & 0.10 & 5.7 & $9.4^{\dagger}$ & 4.6 & 6.2 & 4.7 & 6.2 & 1.1 & 0.05 & 0.18 & 0.61 \\
\hline Isovalerate, mol/100 mol & 0.8 & 1.3 & 0.02 & 0.7 & 0.4 & 0.6 & 0.9 & 0.7 & 0.5 & 0.2 & 0.69 & 0.18 & 0.02 \\
\hline Valerate, mol/100 mol & 1.1 & 1.3 & 0.04 & 1.1 & 0.9 & 1.0 & $0.6^{*}$ & 1.1 & 0.8 & 0.1 & 0.01 & 0.36 & 0.77 \\
\hline Caproate, mol/100 mol & 0.02 & 0.02 & 0.74 & 0.02 & 0.02 & 0.01 & 0.01 & 0.01 & 0.01 & $<0.001$ & 0.75 & 0.30 & 0.67 \\
\hline
\end{tabular}

${ }^{1}$ Treatments were the control (C) or a continuous infusion (I) of $349 \pm 6 \mathrm{mmol}$ of glucose/h into the abomasum from 1 to 29 DIM.

${ }^{2}$ Student's $t$-test for prepartum C to 4 DIM C to differ from prepartum I to 4 DIM I.

${ }^{3} \mathrm{n}=3$.

${ }^{4}$ Fixed effects when prepartum observations are excluded from the data set. Trt $=$ treatment.

${ }^{* *} P \leq 0.01,{ }^{*} P \leq 0.05, \dagger P \leq 0.10$ : symbols signify a difference between LSM within DIM and rows. 
Table 5. Ruminal variables ${ }^{1}$

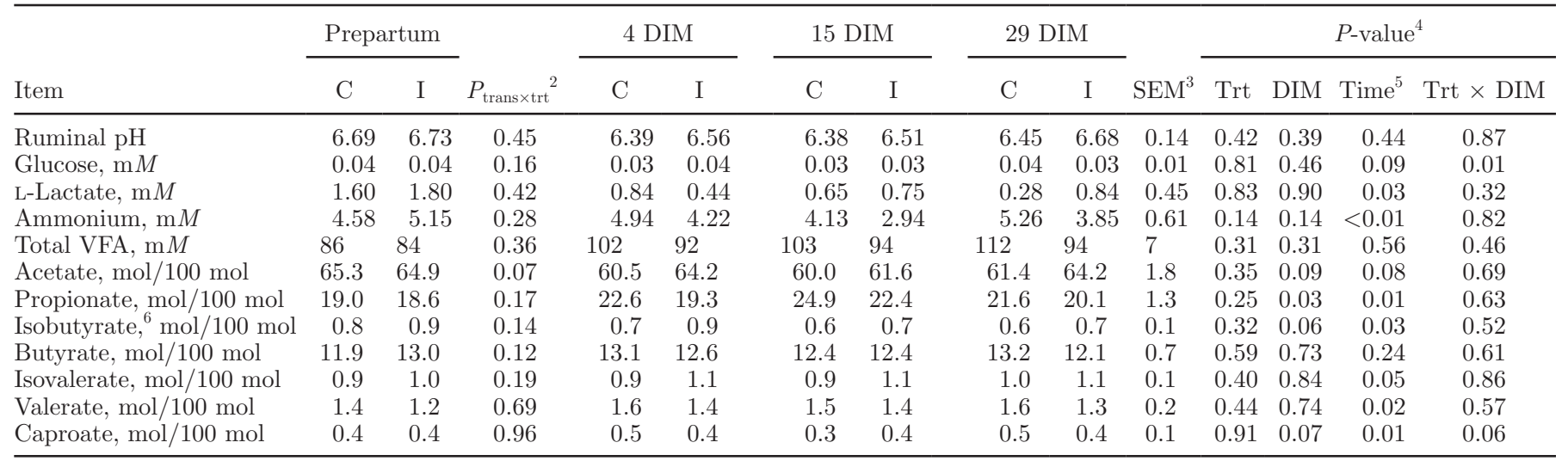

${ }^{1}$ Treatments were the control (C) or a continuous infusion (I) of $349 \pm 6 \mathrm{mmol}$ of glucose/h into the abomasum from 1 to 29 DIM.

${ }^{2}$ Student's $t$-test for prepartum C to 4 DIM C to differ from prepartum I to 4 DIM I.

${ }^{3} \mathrm{n}=3$.

${ }^{4}$ Fixed effects when prepartum observations are excluded from the data set. Trt $=$ treatment.

${ }^{5}$ Time within sampling day.

${ }^{6}$ Tendency for a Trt $\times$ Time interaction $(P \leq 0.10)$.

${ }^{* *} P \leq 0.01,{ }^{*} P \leq 0.05, \dagger P \leq 0.10$ : symbols signify a difference between LSM within DIM and rows.

\section{Blood Flows}

The portal and hepatic blood plasma flows did not increase between prepartum and 4 DIM, and were not affected by treatment during transition $(P=0.19$ to $P$ $=0.56 ;$ Table 7$)$. Postpartum, there tended to be an interaction $(P=0.07)$ between treatment and DIM for the portal blood plasma flow, reflecting a greater rate of increase with the $\mathrm{C}$ than the I treatment. The hepatic vein blood plasma flow was not affected $(P=0.25)$ by treatment and increased $(P<0.01)$ with increasing DIM.

\section{Net Portal Fluxes}

The net portal flux of glucose increased more $(P<$ 0.01) from prepartum to 4 DIM with the I treatment compared with the $\mathrm{C}$ treatment (Table 7). Postpartum, the net portal flux of glucose was greater $(P<0.01)$ with the I than the $\mathrm{C}$ treatment; however, it decreased $(P=0.04)$ with increasing DIM with both treatments. The average increase in net portal flux of glucose with the I treatment was equivalent to $998 \mathrm{~g}$ of glucose/d, and the portal recovery of the infused glucose was 67 $\pm 5 \%$.

There was an interaction $(P<0.01)$ between treatment and DIM for the net portal flux of BHBA, reflecting an increased amount and rate of increase with the $\mathrm{C}$ treatment compared with the I treatment. There tended to be an interaction $(P=0.10)$ between treatment and DIM for the net portal flux of lactate, reflecting an increased amount and rate of increase with the
$\mathrm{C}$ treatment compared with the I treatment. There was an interaction $(P<0.01)$ between treatment and DIM for the net portal flux of oxygen, reflecting an increased amount and rate of increase of PDV uptake with the C treatment compared with the I treatment.

\section{Net Hepatic Fluxes}

The net hepatic flux of glucose tended to increase more $(P=0.09)$ from prepartum to 4 DIM with the $\mathrm{C}$ than the I treatment (Table 7). Postpartum, the net hepatic flux of glucose and BHBA was consistently greater $(P \leq 0.01)$ with the $\mathrm{C}$ than the I treatment but increased $(P \leq 0.01)$ in parallel with both treatments. However, the net hepatic flux of glucose per kilogram of DMI was not affected by treatment $(P=0.68)$ or DIM ( $P=0.12$; data not shown). The net hepatic uptake (negative net flux) of lactate increased more $(P$ $=0.02$ ) from prepartum to 4 DIM with the $\mathrm{C}$ than the I treatment. Postpartum, the net hepatic uptake of lactate was consistently greater $(P<0.01)$ with the $\mathrm{C}$ than the I treatment. The net hepatic uptake of oxygen tended to be greater $(P=0.08)$ with the $\mathrm{C}$ than the I treatment and was not affected $(P=0.21)$ by DIM. The net hepatic flux of carbon dioxide was not affected by treatment $(P=0.42)$ but increased $(P<0.01)$ with increasing DIM.

\section{Net Splanchnic Fluxes}

The net splanchnic flux of glucose was not affected by treatment $(P=0.84)$ from prepartum to 4 DIM 
Table 6. Arterial variables

\begin{tabular}{|c|c|c|c|c|c|c|c|c|c|c|c|c|c|c|}
\hline \multirow[b]{2}{*}{ Item } & \multicolumn{2}{|c|}{ Prepartum } & \multirow[b]{2}{*}{$P_{\text {trans } \times \text { trt }}^{2}$} & \multicolumn{2}{|c|}{4 DIM } & \multicolumn{2}{|c|}{15 DIM } & \multicolumn{2}{|c|}{29 DIM } & \multirow[b]{2}{*}{$\mathrm{SEM}^{3}$} & \multicolumn{4}{|c|}{$P$-value ${ }^{4}$} \\
\hline & $\mathrm{C}$ & I & & $\mathrm{C}$ & I & $\mathrm{C}$ & $\mathrm{I}$ & $\mathrm{C}$ & I & & Trt & DIM & $\operatorname{Time}^{5}$ & $\begin{array}{l}\text { Trt } \times \\
\text { DIM }\end{array}$ \\
\hline \multicolumn{15}{|l|}{ Whole blood } \\
\hline $\mathrm{pH}^{6}$ & 7.46 & 7.48 & 0.36 & 7.45 & 7.46 & 7.43 & 7.43 & 7.44 & 7.45 & 0.01 & 0.35 & $<0.01$ & 0.31 & 0.59 \\
\hline Hematocrit, \% & 25.7 & 24.8 & 0.65 & 27.8 & 27.6 & 24.6 & 26.2 & 23.4 & 23.8 & 1.3 & 0.75 & $<0.01$ & 0.03 & 0.17 \\
\hline $\mathrm{O}_{2},{ }^{6} \mathrm{~m} M$ & 5.19 & 5.03 & 0.41 & 5.56 & 5.63 & 4.93 & 5.35 & 4.70 & 4.87 & 0.27 & 0.62 & $<0.01$ & 0.05 & 0.20 \\
\hline $\mathrm{CO}_{2}, \mathrm{~m} M$ & 23.8 & 25.6 & 0.62 & 24.4 & 26.8 & 24.4 & 24.4 & 25.2 & 26.0 & 1.0 & 0.47 & 0.09 & 0.04 & 0.13 \\
\hline \multicolumn{15}{|l|}{ Blood plasma } \\
\hline $\begin{array}{l}p \text {-Aminohippuric acid, }{ }^{7} \\
\mathrm{~m} M\end{array}$ & 0.071 & 0.094 & 0.33 & 0.083 & 0.090 & 0.070 & 0.076 & 0.071 & 0.074 & 0.012 & 0.75 & 0.12 & 0.06 & 0.95 \\
\hline Glucose, ${ }^{8} \mathrm{~m} M$ & 3.94 & 3.76 & 0.05 & 3.45 & 3.92 & 3.30 & 3.86 & 3.53 & 3.98 & 0.27 & 0.22 & 0.59 & 0.67 & 0.92 \\
\hline L-Lactate, ${ }^{9} \mathrm{~m} M$ & 0.61 & 0.68 & 0.35 & 1.02 & 0.73 & 0.34 & 0.38 & 0.35 & 0.35 & 0.19 & 0.69 & 0.04 & 0.58 & 0.73 \\
\hline NEFA, mM & 0.117 & 0.085 & 0.06 & 0.341 & 0.147 & 0.128 & 0.098 & 0.119 & 0.042 & 0.052 & 0.16 & $<0.01$ & 0.44 & 0.14 \\
\hline BHBA, $\mathrm{m} M$ & 0.575 & 0.561 & $<0.01$ & 0.494 & $0.281^{*}$ & 0.546 & $0.274^{* *}$ & 0.721 & $0.280^{* *}$ & 0.045 & $<0.01$ & $<0.01$ & 0.94 & 0.01 \\
\hline Insulin, $\mathrm{p} M$ & 92 & 55 & 0.03 & 22 & $63^{\dagger}$ & 35 & 58 & 53 & 61 & 17 & 0.07 & 0.57 & 0.09 & 0.55 \\
\hline IGF-I, ng/mL & 179 & 178 & 0.92 & 61 & 57 & 95 & 106 & 134 & 138 & 24 & 0.90 & $<0.01$ & 0.15 & 0.88 \\
\hline
\end{tabular}

${ }^{1}$ Treatments were the control (C) or a continuous infusion (I) of $349 \pm 6 \mathrm{mmol}$ glucose/h into the abomasum from 1 to 29 DIM.

${ }^{2}$ Student's $t$-test for prepartum C to 4 DIM C to differ from prepartum I to 4 DIM I.

${ }^{3} \mathrm{n}=3$.

${ }^{4}$ Fixed effects when prepartum observations are excluded from the data set. Trt $=$ treatment.

${ }^{5}$ Time within sampling day.

${ }^{6}$ Trt $\times$ Time interaction $(P \leq 0.05)$.

${ }^{7}$ Trt $\times$ DIM $\times$ Time interaction $(P \leq 0.05)$.

${ }^{8} \mathrm{DIM} \times$ Time interaction $(P \leq 0.05)$.

${ }^{9}$ Tendency for a Trt $\times$ DIM $\times$ Time interaction $(P \leq 0.10)$.

${ }^{* *} P \leq 0.01,{ }^{*} P \leq 0.05, \dagger P \leq 0.10$ : symbols signify a difference between LSM within DIM and rows. 
Table 7. Blood plasma flows, net fluxes of metabolites, and portal drained visceral (PDV) uptake of arterial glucose

\begin{tabular}{|c|c|c|c|c|c|c|c|c|c|c|c|c|c|c|}
\hline \multirow[b]{2}{*}{ Item } & \multicolumn{2}{|c|}{ Prepartum } & \multirow[b]{2}{*}{$P_{\text {trans } \times \text { trt }}^{2}$} & \multicolumn{2}{|c|}{$4 \mathrm{DIM}$} & \multicolumn{2}{|c|}{15 DIM } & \multicolumn{2}{|c|}{29 DIM } & \multirow[b]{2}{*}{$\mathrm{SEM}^{3}$} & \multicolumn{4}{|c|}{$P$-value ${ }^{4}$} \\
\hline & $\mathrm{C}$ & I & & $\mathrm{C}$ & I & $\mathrm{C}$ & I & $\mathrm{C}$ & I & & Trt & DIM & $\operatorname{Time}^{5}$ & Trt $\times$ DIM \\
\hline \multicolumn{15}{|c|}{ Blood plasma flows, $\mathrm{L} / \mathrm{h}$} \\
\hline Portal vein & 830 & 778 & 0.19 & 988 & 792 & 1,354 & $913^{*}$ & 1,498 & $1,160^{\dagger}$ & 106 & 0.11 & $<0.01$ & 0.12 & 0.07 \\
\hline Hepatic vein & 1,130 & 1,056 & 0.56 & 1,361 & 1,152 & 1,781 & 1,231 & 2,019 & 1,840 & 217 & 0.25 & $<0.01$ & 0.71 & 0.31 \\
\hline Hepatic artery & 337 & 279 & 0.55 & 516 & 361 & 572 & 319 & 581 & 664 & 184 & 0.65 & 0.10 & 0.87 & 0.26 \\
\hline \multicolumn{15}{|c|}{ Net portal whole blood flux, $\mathrm{mmol} / \mathrm{h}$} \\
\hline Oxygen & $-1,551$ & $-1,367$ & 0.22 & $-1,667$ & $-1,255$ & $-2,344$ & $-1,480^{*}$ & $-2,705$ & $-1,657^{*}$ & 173 & 0.04 & $<0.01$ & 0.24 & $<0.01$ \\
\hline Carbon dioxide $^{6}$ & 1,546 & 1,219 & 0.49 & 1,657 & 1,010 & 1,921 & 1,446 & 1,993 & 1,545 & 310 & 0.29 & 0.16 & 0.62 & 0.86 \\
\hline \multicolumn{15}{|c|}{ Net portal plasma flux, mmol/h } \\
\hline Glucose & -37 & -25 & $<0.01$ & -34 & $195^{* *}$ & -43 & $207^{* *}$ & -65 & $150^{* *}$ & 17 & $<0.01$ & 0.04 & 0.14 & 0.58 \\
\hline BHBA & 179 & 154 & 0.20 & 163 & 97 & 222 & $88^{*}$ & 285 & $134^{*}$ & 30 & 0.06 & $<0.01$ & 0.21 & $<0.01$ \\
\hline L-Lactate & 118 & 77 & 0.82 & 113 & $65^{\dagger}$ & 185 & $68^{* *}$ & 194 & $106^{*}$ & 19 & 0.03 & $<0.01$ & 0.53 & 0.10 \\
\hline \multicolumn{15}{|c|}{ Net hepatic whole blood flux, mmol/h } \\
\hline Oxygen & $-2,317$ & $-1,841$ & 0.13 & $-3,333$ & $-1,798^{\dagger}$ & $-3,196$ & $-1,936^{\dagger}$ & $-3,868$ & $-2,691$ & 661 & 0.08 & 0.21 & 0.93 & 0.90 \\
\hline Carbon dioxide & 1,222 & 1,253 & 0.96 & 882 & 944 & 2,722 & 1,770 & 2,451 & 1,980 & 507 & 0.42 & $<0.01$ & 0.23 & 0.14 \\
\hline \multicolumn{15}{|c|}{ Net hepatic plasma flux, mmol/h } \\
\hline Glucose & 496 & 450 & 0.09 & 714 & $462^{* *}$ & 848 & $509^{* *}$ & 954 & $689^{* *}$ & 88 & $<0.01$ & $<0.01$ & 0.67 & 0.84 \\
\hline BHBA & 164 & 130 & 0.15 & 241 & $102 *$ & 259 & $129^{\dagger}$ & 433 & $216^{* *}$ & 54 & 0.01 & 0.01 & 0.93 & 0.49 \\
\hline L-Lactate & -214 & -140 & 0.02 & -509 & $-146^{* *}$ & -146 & -61 & -289 & $-72^{\dagger}$ & 99 & $<0.01$ & 0.11 & 0.65 & 0.40 \\
\hline \multicolumn{15}{|c|}{ Net splanchnic whole blood flux, $\mathrm{mmol} / \mathrm{h}$} \\
\hline Oxygen & $-3,797$ & $-3,230$ & 0.17 & $-4,809$ & $-3,043^{*}$ & $-5,194$ & $-3,412^{*}$ & $-6,477$ & $-4,298^{* *}$ & 710 & 0.03 & 0.02 & 0.91 & 0.89 \\
\hline Carbon dioxide & 2,852 & 2,549 & 0.93 & 2,356 & 1,968 & 3,876 & 3,211 & 4,351 & 3,743 & 662 & 0.38 & $<0.01$ & 0.61 & 0.67 \\
\hline \multicolumn{15}{|c|}{ Net splanchnic plasma flux, $\mathrm{mmol} / \mathrm{h}$} \\
\hline Glucose & 464 & 417 & 0.84 & 680 & 657 & 799 & 717 & 859 & 826 & 92 & 0.46 & 0.07 & 0.68 & 0.94 \\
\hline BHBA & 329 & 284 & 0.22 & 370 & $196^{*}$ & 395 & $217^{\dagger}$ & 679 & $351^{* *}$ & 77 & 0.02 & 0.01 & 0.73 & 0.32 \\
\hline L-Lactate & -96 & -63 & 0.02 & -410 & -81 & 10 & 7 & -113 & 16 & 108 & 0.14 & 0.07 & 0.92 & 0.26 \\
\hline \multicolumn{15}{|c|}{ PDV uptake of arterial glucose } \\
\hline Rate, $\mathrm{mmol} / \mathrm{h}$ & 89 & 46 & 0.15 & 81 & 103 & 105 & 52 & 97 & 150 & 24 & 0.73 & 0.16 & 0.10 & 0.10 \\
\hline Ratio, \% & 2.8 & 1.6 & 0.14 & 2.6 & 3.1 & 2.4 & 1.5 & 2.0 & 3.4 & 0.6 & 0.53 & 0.28 & 0.12 & 0.13 \\
\hline
\end{tabular}

فㄹ ${ }^{1}$ Treatments were the control (C) or a continuous infusion (I) of $349 \pm 6 \mathrm{mmol}$ of glucose/h into the abomasum from 1 to 29 DIM.

2 2 Student's $t$-test for prepartum C to 4 DIM C to differ from prepartum I to 4 DIM I.

${ }^{3} \mathrm{n}=3$, except for net hepatic flux and net splanchnic flux with the $\mathrm{C}$ treatment, where $\mathrm{n}=2$.

₹ $\quad{ }^{4}$ Fixed effects when prepartum observations are excluded from the data set. Trt $=$ treatment.

$\stackrel{\text { }}{\stackrel{5}{\Phi}} \quad{ }^{5}$ Time within sampling day.

${ }^{6}$ Trt $\times$ Time interaction $(P \leq 0.05)$. 
(Table 7). Postpartum, the net splanchnic flux of glucose was not affected $(P=0.46)$ by treatment but tended to increase $(P=0.07)$ with increasing DIM. The net splanchnic uptake (negative net splanchnic flux) of lactate decreased more $(P=0.02)$ from prepartum to 4 DIM with the $\mathrm{C}$ than the I treatment. Postpartum, the net splanchnic flux of lactate was not affected $(P=$ $0.14)$ by treatment. The net splanchnic flux of BHBA was lower $(P=0.02)$ with the I than the $\mathrm{C}$ treatment but increased in parallel $(P=0.01)$ with increasing DIM with both treatments.

\section{PDV Uptake of Arterial Glucose}

The PDV uptake of arterial glucose was not affected $(P=0.73)$ by treatment or by DIM $(P=0.16$; Table $7)$, but there tended to be an interaction $(P=0.10)$ between treatment and DIM, reflecting a low uptake at 15 DIM with I. The PDV extraction ratio of arterial glucose was not affected $(P=0.28$ to $P=0.53)$ by treatment or DIM. Correction of the net portal flux of glucose for PDV uptake of arterial $\left[{ }^{13} \mathrm{C}\right]$ glucose did not affect the treatment difference; that is, the estimated portal recovery of infused glucose was not affected by the correction.

\section{DISCUSSION}

\section{PDV Glucose Metabolism}

Increased PDV uptake of arterial or luminal glucose associated with postruminal infusion of starch and glucose has often been thought to explain some of the glucose not accounted for in portal blood. In the present study, $67 \%$ of the infused glucose was accounted for in the portal blood when assessed by treatment differences in the net portal flux of glucose and was increased to $72 \%$, if corrected for the lower DMI with I, because the lower DMI probably reduced the absorption of glucose from the diet compared with $\mathrm{C}$. The portal recovery of abomasally infused glucose in the present study was in good agreement with the 62 to $67 \%$ observed with similar infusion rates of glucose in steers (Kreikemeier et al., 1991; Kreikemeier and Harmon, 1995). These portal recoveries of glucose are substantially greater than the 20 to $50 \%$ recoveries observed with abomasal infusion of starch in steers (Kreikemeier et al., 1991; Harmon et al., 2001) and in dairy cows (Reynolds et al., 1998), indicating that small intestinal hydrolysis of starch is the limiting factor in the utilization of starch escaping ruminal fermentation.

In contrast to the present findings, PDV uptake of arterial glucose increased with postruminal compared with ruminal starch infusion in steers (Harmon et al., 2001), and the PDV extraction ratio of arterial glucose also increased (1.5\% with ruminal and $2.9 \%$ with postruminal starch infusion, respectively; D. L. Harmon, University of Kentucky, Lexington, personal communication). The PDV extraction ratio of arterial glucose was $1.6 \pm 0.2 \%$ in cows in late lactation fed a low-starch ration (Kristensen et al., 2006), in agreement with observations from steers receiving a ruminal infusion. In the present study, the PDV extraction ratio was $2.5 \pm 0.2 \%$ and was not affected by physiological stage or treatment; the PDV extraction ratio therefore seems rather similar across cattle type, glucogenic status, and physiological stage. The observed robustness in PDV use of arterial glucose might suggest that only a small proportion of the portal blood flow had passed the small intestinal epithelium and that other PDV tissues had relatively low responsiveness to insulin.

In the present study, the net portal flux of lactate did not indicate a substantially greater metabolism of glucose by enterocytes during absorption (first pass metabolism) with the I treatment compared with the $\mathrm{C}$ treatment because the lower net portal flux of lactate with the I treatment could be related to the lower DMI via the concomitant lower metabolism of propionate and valerate in the ruminal epithelium (Kristensen and Harmon, 2006). In studies with cattle in which short-term postruminal infusion of glucose was used, no evidence for substantial first-pass metabolism of glucose has been observed; the portal recovery of infused glucose was $90 \%$ in dairy cows (Larsen and Kristensen, 2007 ) and 108 to $133 \%$ in steers (Kreikemeier et al., 1991; Krehbiel et al., 1996). Short-term infusion of glucose can be used to assess first-pass metabolism of glucose, because a short duration of infusion will minimize the chance for adaptation in both the intestinal microbial flora and the PDV metabolism of glucose to the increased presence of glucose. These "full" portal recoveries indicate a limited first-pass metabolism of glucose, and the present lack of response in portal flux of lactate point to the conclusion that even during longterm infusions, first-pass metabolism of glucose does not explain the glucose not accounted for in the portal blood.

The present experiment provided no clear evidence for an adaptive response in the small intestinal sodiumdependent glucose cotransport to the increased presence of glucose, because the net portal flux of glucose with the I treatment was fairly constant throughout the infusion period. This finding is consistent with the findings in steers (Bauer et al., 2001; Rodriguez et al., 2004). Therefore, the infused glucose not accounted for in the portal blood was probably present in the lumen of the small intestine and eventually also in the colon, and was thus available for microbial fermenta- 
tion therein. In the present study, we found evidence for both glucose spillover to the colon and for colonic fermentation of glucose with the I treatment at 4 DIM, because the concentration of glucose as well as the molar proportion of butyrate increased in the fecal liquid. The altered metabolite profile in the fecal liquid was not observed at 15 and 29 DIM, thus indicating either that the glucose spillover to the colon had decreased or that the colonic fermentation had adapted to the presence of glucose.

Evidence for adaptation of the microbial flora in the distal small intestine to ferment some of the glucose present in the small intestine has been provided in steers by Kreikemeier et al. (1991) and Kreikemeier and Harmon (1995); abomasal infusion of similar amounts of glucose in steers decreased ileal digesta $\mathrm{pH}$ by 0.33 to 0.55 units. Further, Van Kessel et al. (2002) found increased counts of both aerobic and anaerobic bacteria in cecal contents. Adaptation of the microbial flora in the small intestine to ferment some of the glucose present might explain both the glucose unaccounted for in the portal blood and that the spillover of glucose to the colon seemed to be reduced between 4 and 15 DIM. Hypothetically, some of the infused glucose could have escaped the abomasum through backflow to the reticulorumen, but the ruminal variables measured gave no indication of this.

Overall, the absorption of abomasally infused glucose was high $(>67 \%)$. Increased PDV uptake of arterial glucose did not explain the glucose unaccounted for in the portal blood. Instead, the present experiment provides some evidence that the glucose not accounted for in the portal blood was fermented by microbes in the colon and probably also in the small intestine.

\section{Hepatic Glucose Metabolism}

It seems plausible that regulating the size of the hepatic glycogen pool has a central role in maintaining glucose homeostasis in the peripheral blood, via shortterm regulation of glyconeogenesis and glycogenolysis (Reynolds, 1995; Stangassinger and Giesecke, 1986). The hepatic glycogen pool can easily contain $2.5 \mathrm{~mol}$ of glucose in adult cattle (Kristensen et al., 2002), and a large proportion of the measured effects on net hepatic flux of glucose in studies of short duration can thus be ascribed to changes in the hepatic glycogen pool.

The pattern of hepatic flux of glucose through the transition period with the $\mathrm{C}$ treatment was generally similar to that found by Reynolds et al. (2003). With the $\mathrm{C}$ treatment, it is of particular interest that already at 4 DIM, the net hepatic flux of glucose was increased by $45 \%$ relative to the prepartum amount, indicating that the postpartum liver response is fast. It also is interesting to note that this abrupt increase in hepatic glucose release was accompanied by an increased contribution of hepatic arterial blood flow to total liver blood flow, an increased hepatic consumption of oxygen, and a relatively large increase in hepatic as well as net splanchnic uptake of lactate.

With infusion, the net hepatic flux of glucose did not increase as much as with the $\mathrm{C}$ treatment, and the substantially greater insulin concentration with the I than the $\mathrm{C}$ treatment in the very first days of lactation might have played a key role in lowering the net hepatic flux of glucose. The net hepatic release of glucose did not differ between treatments when related to DMI, and this indicates that insulin probably did not act at the level of the liver, but acted indirectly via decreased feed intake and thus decreased the supply of glucogenic precursors from ruminal fermentation. This is further supported by studies with dairy cows in midlactation (Reynolds et al., 1998) and with growing steers (Harmon et al., 2001), in which neither feed intake nor net hepatic flux of glucose was affected by abomasal infusion of starch, despite an increased net portal flux of glucose. The duration of the abomasal infusion in these experiments was at least $8 \mathrm{~d}$; thus, the transient effect of the increased portal glucose supply on the hepatic glycogen pool was probably not influencing the relationship between hepatic uptake of glucogenic precursors and hepatic release of glucose at the time of sampling. Gluconeogenesis is the primary sink for propionate, irrespective of glucogenic status (Danfær et al., 1995); therefore, in the long term, propionate absorption will drive gluconeogenesis even when glucose absorption is excessive, compared with common feeding situations. The increased exogenous glucose supply with the I treatment changed the overall glucose supply to be less dependent on Cori cycle activity, and tissues would have more 3-carbon units available for metabolism, as indicated by a decrease in the maximal contribution of lactate to hepatic gluconeogenesis from $20 \%$ with the $\mathrm{C}$ treatment to $10 \%$ with the I treatment. In summary, gluconeogenesis in the present study seemed to be indirectly affected by the increased absorption of glucose from the small intestine via the lower supply of glucogenic substrates from ruminal fermentation.

\section{Feed Intake and Milk Production}

A lower voluntary DMI of the observed magnitude with the I treatment was not expected, because previous studies infusing $1,500 \mathrm{~g} / \mathrm{d}$ of starch led to a $4 \%$ decrease of DMI in early lactation (Knowlton et al., 1998) and to an 8 to $9 \%$ decrease of DMI in midlactation (Abramson et al., 2005). The decreases in voluntary DMI have been ascribed to the ability of the cows to 
compensate for the additional energy supplied by infusion. A hypothesized mechanism has been that the gut hormone glucagon-like peptide-1 secreted from L cells in the distal small intestine depresses voluntary DMI in response to the presence of carbohydrates in the distal small intestine (Beglinger and Degen, 2006). However, as observed in the present study, the transient nature of secondary responses in fecal metabolite concentrations indicated that glucose was not present in large amounts at the level of the ileum.

The course of voluntary DMI and milk yield with the I treatment seemed to separate from the $\mathrm{C}$ treatment at approximately 3 to 4 DIM, coinciding with glucose infusion reaching $1,500 \mathrm{~g} / \mathrm{d}$ (Figure $2 \mathrm{a}$ and $2 \mathrm{~b}$ ). In very early lactation, the pull of nutrients by the mammary gland leads to decreased plasma concentrations of glucose and insulin and to increased concentrations of NEFA and BHBA (Grummer, 1995), as observed with the $\mathrm{C}$ treatment in the present study. In contrast, changes in the concentrations of these metabolites and hormones could barely be detected with the I treatment, and this profound effect of abomasal glucose infusion on circulating concentrations of metabolites and hormones indicates that the glucogenic status was improved, which normally would be interpreted as a desired reduction in metabolic stress (Grummer, 1995). However, the possible benefits of an improved glucogenic status were hampered by the lower voluntary DMI with the I treatment. The changes normally observed in plasma concentrations of metabolites and hormones are probably part of the endocrine cascade responsible for homeorhesis in the metabolic set point in very early lactation (Bauman, 2000), and we hypothesize that the lower voluntary DMI with the I treatment was caused by a lack of these homeorhetic signals. This is supported by findings of similar decreases in voluntary DMI when using the hyperinsulinemic-euglycemic clamp technique in periparturient dairy cows (Leury et al., 2003).

In the present study, the number of cows prevented us from making strong conclusions on the effects of manipulating glucogenic status on milk yield and DMI responses; however, the data point toward an infusion model as an efficient tool for manipulating the supply of specific nutrients to evaluate some of the long-standing questions on homeorhetic control in very early lactation. That is, are high-yielding cows eating more because they are giving more milk and mobilizing more of their body stores, or are high-yielding cows giving more milk because they eat more (Bauman et al., 1985)? Data from the present study with a small number of cows suggest that a possible biological implication of high glucogenic status in very early lactation is the blockage of parts of the endocrine cascade redirecting nutrients from body reserves to the mammary gland.

\section{CONCLUSIONS}

Abomasal glucose infusion in periparturient dairy cows increased the amount of glucose available for peripheral tissues, but PDV uptake of arterial glucose was not affected by treatment. The increased exogenous supply of glucose changed the overall supply of glucose to become less dependent on the recycling of glucose carbon from lactate and decreased hepatic glucose output; however, hepatic glucose output was not affected by abomasal glucose infusion when related to DMI. Small intestinal glucose absorption is an efficient source of glucose to peripheral tissues of dairy cows in early lactation, and at least $67 \%$ of the available glucose is recovered in the portal vein without affecting hepatic gluconeogenesis. Contrary to our hypothesis, cows on the I treatment produced less milk and had a lower feed intake, indicating that improved glucogenic status in very early lactation impaired metabolic adaptations to lactation.

\section{ACKNOWLEDGMENTS}

We gratefully acknowledge Birgitte M. L. Raun, Birgit H. Løth, Torkild N. Jakobsen, and Kasper B. Poulsen (Faculty of Agricultural Science, Aarhus University) for their skillful and dedicated technical assistance during surgery, care of animals, samplings, and laboratory analyses. We gratefully acknowledge the staff of K-33, D-23, and K-42 (Faculty of Agricultural Sciences, Aarhus University) for their hard work and skillful assistance. Funding for the experiment was provided by the Danish Cattle Federation (Aarhus, Denmark) and the Faculty of Agricultural Sciences, Aarhus University. M. Larsen was supported by an Industrial PhD fellowship program under the Danish Ministry of Science, Technology and Innovation (Copenhagen, Denmark). The present fellowship was held by the Faculty of Life Sciences, University of Copenhagen (Frederiksberg, Denmark), the Institute for Agro Technology and Food Innovation (Aarhus, Denmark), and the Faculty of Agricultural Sciences, Aarhus University (Tjele, Denmark).

\section{REFERENCES}

Abramson, S. M., I. Bruckental, L. Lipshitz, U. Moalem, S. Zamwel, and A. Arieli. 2005. Starch digestion site: Influence of ruminal and abomasal starch infusion on starch digestion and utilization in dairy cows. Anim. Sci. 80:201-207.

Bauer, M. L., D. L. Harmon, D. W. Bohnert, A. F. Branco, and G. B. Huntington. 2001. Influence of $\alpha$-linked glucose on sodium-glucose cotransport activity along the small intestine in cattle. J. Anim. Sci. 79:1917-1924.

Bauman, D. E. 2000. Regulation of nutrient partitioning during lactation: Homeostasis and homeorhesis revisited. Pages 311-328 in Ruminant Physiology: Digestion, Metabolism, Growth and Reproduction. P. B. Cronje, ed. CAB International, Wallingford, UK. 
Bauman, D. E., S. N. McCutcheon, W. D. Steinhour, P. J. Eppard, and S. J. Sechen. 1985. Sources of variation and prospects for improvement of productive efficiency in the dairy cow: A review. J. Anim. Sci. 60:583-592.

Beglinger, C., and L. Degen. 2006. Gastrointestinal satiety signals in humans-Physiologic roles for GLP-1 and PYY? Physiol. Behav. 89:460-464.

Bell, A. W. 1995. Regulation of organic nutrient metabolism during transition from late pregnancy to early lactation. J. Anim. Sci. 73:2804-2819.

Danfær, A., V. Tetens, and N. Agergaard. 1995. Review and an experimental study on the physiological and quantitative aspects of gluconeogenesis in lactating ruminants. Comp. Biochem. Physiol. B Biochem. Mol. Biol. 111:201-210.

Drackley, J. K. 1999. Biology of dairy cows during the transition period: The final frontier? J. Dairy Sci. 82:2259-2273.

Drackley, J. K., T. R. Overton, and G. N. Douglas. 2001. Adaptations of glucose and long-chain fatty acid metabolism in liver of dairy cows during the periparturient period. J. Dairy Sci. 84(E Suppl.):E100-E112.

Frystyk, J., B. Dinesen, and H. Ørskov. 1995. Non-competitive timeresolved immunofluorometric assays for determination of human insulin-like growth factor I and II. Growth Regul. 5:169-176.

Grummer, R. R. 1995. Impact of changes in organic nutrient metabolism on feeding the transition dairy cow. J. Anim. Sci. 73:2820-2833.

Harmon, D. L., C. J. Richards, K. C. Swanson, J. A. Howell, J. C. Matthews, A. D. True, G. B. Huntington, S. A. Gahr, and R. W. Russel. 2001. Influence of ruminal or postruminal starch on visceral glucose metabolism in steers. Pages 273-276 in Energy Metabolism in Animals. A. Chwalibog and K. Jakobsen, ed. Wageningen Press, Wageningen, the Netherlands.

Harmon, D. L., R. M. Yamka, and N. A. Elam. 2004. Factors affecting intestinal starch digestion in ruminants: A review. Can. J. Anim. Sci. 84:309-318.

Harvey, R. B., and A. J. Brothers. 1962. Renal extraction of paraaminohippurate and creatine measured by continuous in vivo sampling of arterial and renal-vein blood. Ann. N. Y. Acad. Sci. 102:46-54.

Knowlton, K. F., T. E. Dawson, B. P. Glenn, G. B. Huntington, and R. A. Erdman. 1998. Glucose metabolism and milk yield of cows infused abomasally or ruminally with starch. J. Dairy Sci. 81:3248-3258.

Krehbiel, C. R., R. A. Britton, D. L. Harmon, J. P. Peters, R. A. Stock, and H. E. Grotjan. 1996. Effects of varying levels of duodenal or midjejunal glucose and 2-deoxyglucose infusion on small intestinal disappearance and net portal glucose flux in steers. J. Anim. Sci. 74:693-700.

Kreikemeier, K. K., and D. L. Harmon. 1995. Abomasal glucose, maize starch and maize dextrin infusions in cattle: Small-intestinal disappearance, net portal glucose flux and ileal oligosaccharide flow. Br. J. Nutr. 73:763-772.

Kreikemeier, K. K., D. L. Harmon, R. T. Brandt Jr., T. B. Avery, and D. E. Johnson. 1991. Small intestinal starch digestion in steers: Effect of various levels of abomasal glucose, corn starch, and corn dextrin infusion on small intestinal disappearance and net glucose absorption. J. Anim. Sci. 69:328-338.

Kristensen, N. B., A. Danfær, B. A. Røjen, B. M. L. Raun, M. R Weisbjerg, and T. Hvelplund. 2002. Metabolism of propionate and 1,2-propanediol absorbed from the washed reticulorumen of lactating cows. J. Anim. Sci. 80:2168-2175.

Kristensen, N. B., A. Danfær, V. Tetens, and N. Agergaard. 1996. Portal recovery of intraruminally infused short-chain fatty acids in sheep. Acta Agric. Scand. Anim. Sci. 46:26-38.
Kristensen, N. B., and D. L. Harmon. 2006. Splanchnic metabolism of short-chain fatty acids in the ruminant. Pages 249-265 in Ruminant Physiology: Digestion, Metabolism and Impact of Nutrition on Gene Expression, Immunology and Stress. K. Sejrsen, T. Hvelplund, and M. O. Nielsen, ed. Wageningen Academic Publishers, Wageningen, the Netherlands.

Kristensen, N. B., B. M. L. Raun, and B. A. Røjen. 2006. Splanchnic metabolism of $\left[\mathrm{U}_{-}{ }^{13} \mathrm{C}\right]$ glucose in lactating dairy cows. J. Dairy Sci 89(Suppl. 1):73. (Abstr.)

Kristensen, N. B., A. Storm, B. M. L. Raun, B. A. Røjen, and D. L. Harmon. 2007. Metabolism of silage alcohols in lactating dairy cows. J. Dairy Sci. 90:1364-1377.

Larsen, M., and N. B. Kristensen. 2007. Portal recovery of glucose infused into the abomasum of lactating dairy cows. Pages 341-342 in Energy and Protein Metabolism and Nutrition. I. OrtiguesMarty, ed. Wageningen Academic Publishers, Wageningen, the Netherlands.

Leury, B. J., L. H. Baumgard, S. S. Block, N. Segoale, R. A. Ehrhardt, R. P. Rhoads, D. E. Bauman, A. W. Bell, and Y. R. Boisclair. 2003. Effect of insulin and growth hormone on plasma leptin in periparturient dairy cows. Am. J. Physiol. Regul. Integr. Comp. Physiol. 285:R1107-R1115.

Løvendahl, P., and H. M. Purup. 2002. Technical note: Time-resolved fluoro-immunometric assay for intact insulin in livestock species. J. Anim. Sci. 80:191-195.

Reynolds, C. K. 1995. Quantitative aspects of liver metabolism in ruminants. Pages 351-371 in Ruminant Physiology: Digestion, Metabolism, Growth and Reproduction. W. von Engelhardt, S. Leonhard-Marek, G. Breves, and D. Giesecke, ed. Ferdinand Enke Verlag Stuttgart, Stuttgart, Germany.

Reynolds, C. K., P. C. Aikman, B. Lupoli, D. J. Humphries, and D. E. Beever. 2003. Splanchnic metabolism of dairy cows during the transition from late gestation through early lactation. J. Dairy Sci. 86:1201-1217.

Reynolds, C. K., D. J. Humphries, S. B. Cammell, J. Benson, J. D. Sutton, and D. E. Beever. 1998. Effects of abomasal wheat starch infusion on splanchnic metabolism and energy balance of lactating dairy cows. Pages 39-42 in Energy Metabolism in Farm Animals. K. J. McCracken, E. F. Unsworth, and A. R. G. Wylie, ed. CAB International., Wallingford, UK.

Rodriguez, S. M., K. C. Guimaraes, J. C. Matthews, K. R. Mc, R. L. Leod, V. I. Baldwin, and D. L. Harmon. 2004. Influence of abomasal carbohydrates on small intestinal sodium-dependent glucose cotransporter activity and abundance in steers. J. Anim. Sci. 82:3015-3023.

Sjaunja, L. O., L. Bævre, L. Junkkarinen, J. Pedersen, and J. Setälä. 1991. A Nordic proposal for an energy corrected milk (ECM) formula. Pages 156-157 in Proc. 27th Session of International Committee for Recording Productivity of Milk Animals (ICRPMA) Eur. Assoc. Anim. Prod. Publ. No. 50. Eur. Assoc. Anim. Prod., Wageningen, the Netherlands.

Stangassinger, M., and D. Giesecke. 1986. Splanchnic metabolism of glucose and related to energy substrates. Pages 347-366 in Control of Digestion and Metabolism in Ruminants. L. P. Milligan, W. L. Grovum, and A. Dobson, ed. Prentice Hall, Englewood Cliffs, NJ.

Van Kessel, J. S., P. C. Nedoluha, A. Williams-Campbell, R. L. Baldwin IV, and K. R. McLeod. 2002. Effects of ruminal and postruminal infusion of starch hydrolysate or glucose on the microbial ecology of the gastrointestinal tract in growing steers. J. Anim. Sci. 80:3027-3034 